\title{
THE EFFECT OF PROFITABILITY, LIQUIDITY, FIRM SIZE AND MEDIA EXPOSURE ON CORPORATE SOCIAL RESPONSIBILITY DISCLOSURE IN INDONESIAN NON- BANKING STATE-OWNED ENTERPRISES
}

\author{
Revaldo Andreas Arnes, Rusmanto Toto* \\ Department of Accounting, Faculty of Economics and Communications, \\ Bina Nusantara University, Jakarta, Indonesia \\ *E-mail: trusmanto@binus.edu
}

\begin{abstract}
The purpose of this study is to determine the effect of profitability, liquidity, firm size and media exposure on corporate social responsibility disclosure at non-banking state-owned enterprises listed on the Indonesia Stock Exchange for 2013-2017 period. The number of samples of this study is 14 of non-banking state-owned enterprises that were taken by sample selection method using purposive sampling. The data analysis method used is panel data regression analysis. The data were analyzed using Eviews software. Based on the analysis result, it shows that partially and simultaneously profitability, liquidity, firm size and media exposure have non-significant effect on corporate social disclosure at non-banking state-owned enterprises in Indonesia.
\end{abstract}

\section{KEY WORDS}

Profitability, corporate social responsibility, firm size, liquidity, media exposure.

In this globalization era, corporate social responsibility (CSR) is getting more popular worldwide, including in Indonesia that has established a regulation regarding the corporate responsibility; the regulation is written in Indonesia's law No. 40 of 2007 in accordance to article 74 of the Limited Liability Company Law. The concordance between the profitability of the company and the direct contribution to the society and its environment is a check and balance mechanism between the company and the community [1]. In other words, CSR is also seen as a benchmark for a company's reputation. Increasing the company's reputation, the trust of society on the company's performance will have a good impact on the company's sales. Corporate Social Responsibility is one of the company's responsibility towards stakeholders [2].

The reason behind the implementation of CSR can influenced by many benefits that company may get from implementing CSR. One of the benefits is the company will be more attractive to investors. Therefore, these days many companies are more aggressive in implementing CSR. CSR is not the way you distribute profits, it is the way you make profits [3]. This study will discuss several factors that influence CSR disclosure. The first variable is profitability. Profitability illustrates the ability of a company to generate profit. In this study, the profitability is proxied by Return on Assets (ROA). ROA itself shows how efficient the company is in managing company assets to make a profit. As stated by Gitman \& Zutter [4], "The return on assets (ROA), often called the return on investment (ROI), measures the overall effectiveness of management in generating profits with its available assets. The higher the firm's return on total assets, the better". ROA addresses the company's ability to obtain a return on total assets owned by the company.

The second variable in this study is a liquidity ratio that will be proxied by quick ratio (QR). QR illustrates the company's ability to pay the short-term debt using the company's most liquid assets. This is because non-current assets owned by a company require a long time to be disbursed into cash. The next variable is the firm size. Large companies are considered to have more advantages compared to small companies. As large companies have more resources, they are relatively more resistant to economic crisis. Based on the statement above, it can be predicted that investors are more attracted to invest in a bigger company. 
The last variable is media exposure. As stated by Morrisan [5], the certain organization or certain corporate sometimes need media to expose or publish their activity. Nowadays, there are many corporations that use digital media to communicate their activity. One of the activities that can be published is the CSR implemented by the corporate. This study used non-banking state-owned enterprise companies for the samples. The selected samples in this study are used to find out how obedient a state-owned enterprise in carrying out CSR activities and disclose them in annual report.

\section{METHODS OF RESEARCH}

The research method used in this study is the associative research method, this method is used to determine the relationship between two or more variables. The object of this study is the financial report and annual report of non-banking state-owned enterprises listed on the Indonesia Stock Exchange for the 2013-2017 period. The sample collection method used in this study is the purposive sampling method which is done by determining the criteria to get the sample needed for this study. The type of data in this study is quantitative. The secondary data is obtained from the official website of each company and the Indonesia Stock Exchange. The data analysis techniques used in this study are panel data regression and data presentation methods using tables, graphs, and explanations with words. The population is a generalization area consisting of objects or subjects that have certain qualities and characteristics determined by researchers to be studied [6]. Based on this understanding, it can be concluded that the population used in this study is a nonbanking state-owned enterprise companies listed on the Indonesia Stock Exchange during the study period. Below is the conducted sample selection process: (i) Companies registered consecutively on the Indonesia Stock Exchange during the period of 2013-2017; (ii) Companies that publish annual reports during the study period.

This study used two types of variables, the independent variable (X1-4) and the dependent variable (Y). The independent variables are Profitability (Return on Assets), Liquidity (Quick Ratio), Firm Size (Total Assets), and Media Exposure. While the dependent used in this study is Corporate Social Responsibility Disclosure. The explanation of variables is as follows:

1. Profitability $\left(X_{1}\right)$. In this study, profitability is proxied by Return on Assets. The formula used to measure ROA [7] is:

$$
\text { ROA }=\frac{\text { Net Profit }}{\text { Total Assets }}
$$

2. Liquidity $\left(\mathrm{X}_{2}\right)$. The liquidity is proxied with Quick Ratio. The formula used to measure the quick ratio is [8]:

$$
\text { Quick Ratio }=\frac{\text { Cash }+ \text { Short term Investment }+ \text { Receivable }(\text { Net })}{\text { Current Liabilities }}
$$

3. Firm Size $\left(\mathrm{X}_{3}\right)$. The firm size is proxied by Total asset. The formula used to measure the firm size is:

$$
\text { Company Size }=\text { Total Asset }
$$

4. Media Exposure $\left(X_{4}\right)$. The measurement of media exposure is done with a dummy variable below [9]: $1=$ The company discloses CSR activities on the company's website; $0=$ The company does not disclose CSR activities on the company's website.

5. Disclosure of Corporate Social Responsibility $(Y)$. Guidelines for disclosure of corporate social responsibility in this study refer to GRI version G4.0. The tools for corporate social responsibility disclosure are 91 points. The calculation of CSR disclosures is carried out as follows:

$$
\operatorname{CSRD}=\frac{\text { The Amount of CSR Disclosures }}{91 \text { Items of CSR Disclosures with GRI version }}
$$




\section{RESULTS OF STUDY}

The type of data used in this study is panel data, which is a combination of time series data and cross-section data. There are three estimation models; the first is the Common Effect Model, Fixed Effect Model, and Random Effect Model. The Common Effect Model is the simplest model. In this model, it is assumed that the behavior of the company data is the same in any periods. Below are the results of common effect model:

Table 1 - Results of Descriptive Statistics Analysis

\begin{tabular}{|c|c|c|c|c|c|}
\hline & ROA & QR & FS & MEDIA EXPOSURE & CSRD \\
\hline Mean & 0.053960 & 1.541301 & 17.08826 & 0.842857 & 0.392779 \\
\hline Median & 0.037519 & 1.178011 & 17.22775 & 1.000000 & 0.368132 \\
\hline Maximum & 0.289626 & 11.95191 & 19.10622 & 1.000000 & 0.956044 \\
\hline Minimum & -0.119960 & -0.022672 & 13.13496 & 0.000000 & 0.098901 \\
\hline Std. Dev. & 0.072944 & 1.893753 & 1.055824 & 0.366563 & 0.165811 \\
\hline
\end{tabular}

Table 2 - Common Effect Model Results

\begin{tabular}{|c|c|c|}
\hline Variable & Coefficient & Probability \\
\hline $\mathrm{C}$ & 1.031821 & 0.01017 \\
\hline $\mathrm{X}_{1}$ & -0.094036 & 0.7393 \\
\hline $\mathrm{X}_{2}$ & -0.006865 & 0.5714 \\
\hline $\mathrm{X}_{3}$ & -0.033230 & 0.1294 \\
\hline $\mathrm{X}_{4}$ & -0.065909 & 0.2469 \\
\hline & \\
\hline R-squared 0.046621 & \\
\hline Adjusted R-squared -0.012049 & \\
\hline F-statistic 0.794637 & \multicolumn{2}{|}{} \\
\hline Prob(F-statistic) 0.532969 & \\
\hline
\end{tabular}

To assume the differences between individuals, this study used the fixed effect model.

Table 3 - Fixed Effect Model Results

\begin{tabular}{|c|c|c|}
\hline Variable & Coefficient & Probability \\
\hline $\mathrm{C}$ & 0.584401 & 0.4712 \\
\hline $\mathrm{X}_{1}$ & -0.182876 & 0.7016 \\
\hline $\mathrm{X}_{2}$ & -0.016337 & 0.2867 \\
\hline $\mathrm{X}_{3}$ & -0.006346 & 0.8933 \\
\hline $\mathrm{X}_{4}$ & -0.057103 & 0.4883 \\
\hline & \\
\hline R-squared 0.430140 & \\
\hline Adjusted R-squared 0.243840 & \\
\hline F-statistic 2.308854 & \\
\hline Prob. (F-statistic) 0.010785 & \\
\hline
\end{tabular}

The random effect model is a model that estimates panel data where interruption variables may be interconnected. In this model, intercept differences are accommodated by the error terms of each company.

Table 4 - Random Effect Model Results

\begin{tabular}{|c|c|c|}
\hline Variable & Coefficient & Probability \\
\hline $\mathrm{C}$ & 0.930226 & 0.0629 \\
\hline$X_{1}$ & -0.152601 & 0.6604 \\
\hline $\mathrm{X}_{2}$ & -0.009965 & 0.4326 \\
\hline$X_{3}$ & -0.027218 & 0.33122 \\
\hline $\mathrm{X}_{4}$ & -0.057840 & 0.3841 \\
\hline \multicolumn{3}{|l|}{ R-squared 0.032088} \\
\hline \multicolumn{3}{|c|}{ Adjusted R-squared $-0,027475$} \\
\hline \multicolumn{3}{|l|}{ F-statistic 0.538722} \\
\hline Prob. (F-statistic) 0.707786 & & \\
\hline
\end{tabular}


To obtain and select the best panel data model, it is necessary to perform statistical tests as follows.

Chow Test. The chow test is used to obtain the estimation model that will be chosen, whether a common effect model or a fixed-effect model. The decision criteria in this test are:

1. Hypothesis design: $\mathrm{HO}=$ Common Effect Model; $\mathrm{Ha}=$ Fixed Effect Model.

2. Decisions to be taken are based on:

- $\mathrm{H} 0$ is rejected if the cross-section $\mathrm{F}$ and Chi-Square probability values are $<0.05$;

- $\mathrm{HO}$ is accepted if the cross-section $\mathrm{F}$ and Chi-Square probability values are $>0.05$.

Table 5 - Chow Test Results

\begin{tabular}{|c|c|c|c|}
\hline Effects Test & Statistic & d.f. & Prob. \\
\hline Cross-section $F$ & 2.692025 & $(13,52)$ & 0.0057 \\
\hline Cross-section Chi-square & 36.023555 & 13 & 0.0006 \\
\hline
\end{tabular}

Based on the results shown in table 5, the results obtained from the chow test are the cross-section $\mathrm{F}$ probability with a value of $0.0057<0.05$ and the Chi-square cross-section probability that is $<0.0006$. Therefore, $\mathrm{H} 0$ is rejected and the selected regression model is the Fixed Effect Model.

Lagrange Multiplier (LM) Test. Lagrange multiplier test is used to obtain the estimated model to be chosen, between the common effect model and the random effect model. The criteria for this test are:

1. Hypothesis design: $\mathrm{HO}=$ Common Effect Model; $\mathrm{Ha}=$ Random Effect Model.

2. Decisions to be taken are based on:

- $\mathrm{H} 0$ is rejected if the Breusch-Pagan (BP) probability value is $<0.05$;

- $\mathrm{H} 0$ is accepted if the Breusch-Pagan (BP) probability value is $>0.05$.

Table 6 - Lagrange Multiplier Test Results

\begin{tabular}{|l|c|c|c|}
\hline \multicolumn{3}{|c|}{ Hypothesis Test } \\
\hline \multirow{3}{*}{ Breusch-Pagan } & Cross-section & Time & Both \\
\cline { 2 - 4 } & 8.134486 & 1.339513 & 9.474000 \\
\cline { 2 - 4 } & $(0.0043)$ & $(0.2471)$ & $(0.0021)$ \\
\hline
\end{tabular}

Based on the results shown in table 6, the results obtained from the Lagrange multiplier (LM) test are the Breusch-Pagan (BP) with probability value of $0.0021<0.05$. Therefore, $\mathrm{H} 0$ is rejected and the selected regression model is the Random Effect Model.

Hausman Test. Hausman test is used to obtain the estimation model to be chosen, either the random effect model or the fixed effect model. The criteria for this test are:

1. Hypothesis design: $\mathrm{HO}=$ Random Effect Model; $\mathrm{Ha}=$ Common Effect Model.

2. Decisions to be taken are based on:

- $\mathrm{H} 0$ is rejected if the probability value is $<0.05$;

- $\mathrm{H} 0$ is accepted if the probability value is $>0.05$.

Here are the results of the Hausman test that has been carried out:

Table 7 - Hausman Test Results

\begin{tabular}{|c|c|c|c|}
\hline Test Summary & Chi-Sq. Statistic & Chi-Sq. d.f. & Prob. \\
\hline Cross-section random & 0.677981 & 4 & 0.9540 \\
\hline
\end{tabular}

Based on the results shown in Table 7, the result obtained from the Hausman test is the probability value of $0.9540>0.05$. Therefore, $\mathrm{HO}$ is accepted and the chosen regression model is the Random Effect Model.

After conducting the three estimation model tests in panel data, based on the explanation above, it can be concluded that the best panel data model is the Random Effect Model. 
Normality test. A normality test is a test used to assess the distribution of data to determine whether the data used in this study is normally distributed or not. The criteria in a normality test decision are:

1. Hypothesis design: $\mathrm{HO}=$ data normally distributed; $\mathrm{Ha}=$ data not normally distributed.

2. Decisions to be taken are based on:

- $\mathrm{H} 0$ is rejected if the Jarque Bera $(\mathrm{JB})$ probability value $<0.05$;

- $\mathrm{H} 0$ is accepted if the Jarque Bera (JB) probability value $>0.05$.

Following are the results of the normality test that have been carried out:

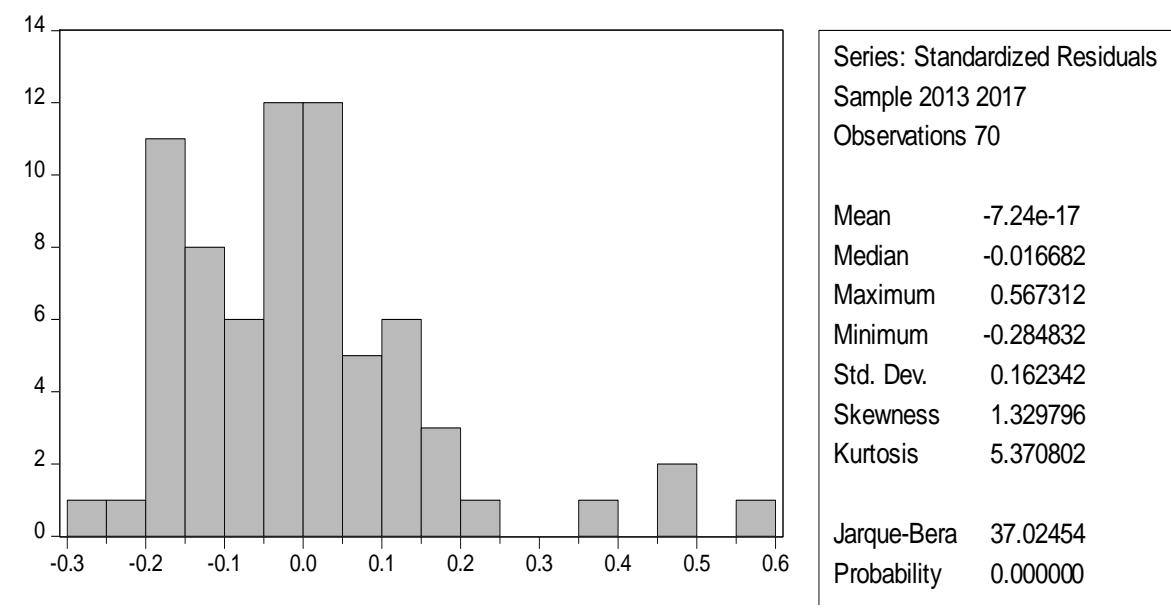

Figure 1 - Normality Test Results

Based on the normality test results shown in Figure 1, it shows that the probability value of Jarque-Bera $(\mathrm{JB})$ is $0.0000<0.05$, so it can be concluded that $\mathrm{HO}$ is rejected and $\mathrm{Ha}$ is accepted which indicates that the data are not normally distributed. But according to Cahyono, if the number of data is more than 30 numbers $(n>30)$, it can be assumed that the data is normally distributed [10]. Therefore, the classical assumption test continues even though the data is not normally distributed with the assumption that the data used in this study are normal because there are more than 30 data.

Heteroscedasticity Test. The heteroscedasticity test is a test used to assess whether there is a difference in variance for all observations of a linear regression model. In this study, the heteroscedasticity test uses the Glejser test. The criteria in the normality test decision making are:

1. Hypothesis design: $\mathrm{HO}=$ absence of heteroscedasticity; $\mathrm{Ha}=$ heteroscedasticity.

2. Decisions to be taken are based on:

- $\mathrm{HO}$ is rejected if the probability value is $<0.05$;

- $\mathrm{H} 0$ is accepted if the probability value is $>0.05$.

Table 8 - Heteroscedasticity Test Result

\begin{tabular}{|c|c|}
\hline Variable & Prob. \\
\hline C & 0.2476 \\
\hline ROA & 0.8005 \\
\hline QR & 0.9932 \\
\hline FS & 0.4786 \\
\hline MEDIA_EXPOSURE & 0.5769 \\
\hline
\end{tabular}

Multicollinearity Test. A multicollinearity test is used to find out whether there is a relationship between independent variables. The criteria in multicollinearity test decision making are:

1. Hypothesis design: $\mathrm{HO}=$ absence of multicollinearity; $\mathrm{Ha}=$ the presence of multicollinearity. 
2. Decisions to be taken are based on:

- $\mathrm{H} 0$ is rejected if the correlation coefficient is $>0.8$;

- $\mathrm{H} 0$ is accepted if the correlation coefficient is $<0.8$.

Table 9 - Multicollinearity Test Results

\begin{tabular}{|c|c|c|c|c|}
\hline $\mathrm{n} / \mathrm{n}$ & $\mathrm{ROA}$ & $\mathrm{QR}$ & $\mathrm{FS}$ & MEDIA EXPOSURE \\
\hline $\mathrm{ROA}$ & 1 & 0.207200488 & -0.090946491 & 0.000344129 \\
\hline $\mathrm{QR}$ & 0.207200488 & 1 & -0.427360423 & -0.049132690 \\
\hline FS & -0.090946491 & -0.427360423 & 1 & -0.189647126 \\
\hline MEDIA EXPOSURE & 0.000344129 & -0.049132690 & -0.189647126 & 1 \\
\hline
\end{tabular}

Statistical Test Results. Based on the estimation model testing, the random effect model was chosen as the best method in analyzing the regression model in this study.

Table 10 - Random Effect Model Panel Data Regression Test Results

\begin{tabular}{|c|c|c|}
\hline Variable & Coefficient & Probability \\
\hline $\mathrm{C}$ & 0.930226 & 0.0629 \\
\hline $\mathrm{X}_{1}$ & -0.152601 & 0.6604 \\
\hline $\mathrm{X}_{2}$ & -0.009965 & 0.4326 \\
\hline $\mathrm{X}_{3}$ & -0.027218 & 0.33122 \\
\hline $\mathrm{X}_{4}$ & -0.057840 & 0.3841 \\
\hline & \\
\hline R-squared 0.032088 & \\
\hline Adjusted R-squared -0,027475 & \\
\hline F-statistic 0.538722 & \multicolumn{2}{|}{} \\
\hline Prob. (F-statistic) 0.707786 & \multicolumn{2}{|}{} \\
\hline
\end{tabular}

Based on table 10, the regression equation models obtained are as follows:

$$
Y=0.930226-0.152601 X_{1}-0.009965 X_{2}-0.027218 X_{3}-0.057840 X_{4}
$$

Where: $Y=$ Dependent Variable (Corporate Social Responsibility Disclosure); $\mathrm{X}_{1}=$ Independent Variable (Return on Asset); $\mathrm{X}_{2}=$ Independent Variable (Quick Ratio); $\mathrm{X}_{3}=$ Independent Variable (Firm Size); $\mathrm{X}_{4}=$ Independent Variable (Media Exposure).

Simultaneous Test Results ( $F$ Test). In this study, the f test was conducted to test whether the independent variables simultaneously influence the dependent variable. The basis for decision making in the $F$ test is based on the significance value. The decision criteria in this test are:

1. Hypothesis design: $\mathrm{HO}=$ Independent variables cannot influence the disclosure of corporate social responsibility simultaneously; $\mathrm{Ha}=$ Independent variables influence the disclosure of corporate social responsibility simultaneously.

2. Decisions to be taken are based on:

- If the significance value is $<0.05$, then $\mathrm{HO}$ is rejected and $\mathrm{Ha}$ is accepted, which means that the independent variables simultaneously have a significant effect on the dependent variable;

- If the significance value is $>0.05$ then $\mathrm{HO}$ is accepted and $\mathrm{Ha}$ is rejected, which means that the independent variables simultaneously have no significant effect on the dependent variable.

The following table shows the results of simultaneous test;

Table 11: F Test Results

\begin{tabular}{|c|c|c|c|}
\hline \multicolumn{4}{|c|}{ Weighted Statistics } \\
\hline R-squared & 0.032088 & Mean dependent var. & 0.202144 \\
\hline Adjusted R-squared & -0.027475 & S.D. dependent var. & 0.138562 \\
\hline S.E. of regression & 0.140452 & Sum squared resid. & 1.282245 \\
\hline F-statistic & 0.538722 & Durbin-Watson stat. & 2.261950 \\
\hline Prob. (F-statistic) & \multicolumn{3}{|c|}{0.707786} \\
\hline
\end{tabular}


Based on table 11 , the statistical $F$ value is 0.538722 , where the value is greater than the significance value of 0.005 . Then it can be concluded, $\mathrm{HO}$ is accepted and $\mathrm{Ha}$ is rejected because the statistical value obtained is greater than 0.005 .

Partial Test (T-Test). In this study, the t-test or often interpreted as a partial test is done to partially test the independent variables on the dependent variable. If the probability value of $t$ or significance is $<0.05$, it can be concluded that there is an influence between the independent variables on the dependent variable partially. However, if the probability value of $t$ is $>0.05$, it can be said that there is no significant effect between each independent variable on the dependent variable, with the following hypothesis:

1. Hypothesis design: $\mathrm{HO}=$ Partially there is no significant influence between the independent variables on the dependent variable; $\mathrm{Ha}=$ Partially there is a significant influence between the independent variables on the dependent variable.

Table 12 - T-Test Results

\begin{tabular}{|c|c|c|}
\hline Variable & Coefficient & Prob. \\
\hline C & 0.930226 & 0.0629 \\
\hline ROA & -0.152601 & 0.6604 \\
\hline QR & -0.009965 & 0.4326 \\
\hline FS & -0.027218 & 0.3312 \\
\hline MEDIA_EXPOSURE & -0.057840 & 0.3841 \\
\hline
\end{tabular}

Coefficient of Determination Test $\left(R^{2}\right)$. The coefficient of determination is used to illustrate the proximity of the regression relationship between the dependent variable and independent variables. The higher the value of $\mathrm{R}^{2}$, the more accurate the estimation of the regression model.

Table $13-R^{2}$ Test Results

\begin{tabular}{|c|c|c|c|}
\hline \multicolumn{4}{|c|}{ Weighted Statistics } \\
\hline R-squared & 0.032088 & Mean dependent var. & 0.202144 \\
\hline Adjusted R-squared & -0.027475 & S.D. dependent var. & 0.138562 \\
\hline S.E. of regression & 0.140452 & Sum squared resid. & 1.282245 \\
\hline F-statistic & 0.538722 & Durbin-Watson stat. & 2.261950 \\
\hline Prob (F-statistic) & 0.707786 & & \\
\hline
\end{tabular}

The table above shows the adjusted $R^{2}$ value of -0.027475 . If the adjusted $R^{2}$ value in the empirical test is negative, then the adjusted $R^{2}$ value is considered zero [11]. Therefore, as the adjusted value of $R^{2}$ is equal to 0 , it means the variable in this study does not influence the independent variable.

\section{DISCUSSION OF RESULTS}

Based on the statistical results of this study, the probability proxied by ROA has an insignificant negative effect on the disclosure of corporate social responsibility; this can be proven by the t test results with the value of 0.6604 . The value of 0.6604 is higher than the significance level of 0.05 , this means that ROA has an insignificant effect. In addition, the result of the coefficient level on ROA is -0.152601 , the value illustrates that ROA has a negative effect on the disclosure of corporate social responsibility. Based on that, it can be concluded that profitability had an insignificant negative effect on the disclosure of corporate social responsibility. he results of this study, part of the research conducted by Priyatno \& Sarsiti (2014) which produced ROA variables did not use partial on CSR. However, this research does not oppose the research conducted by Hainun \& Nurdiawansyah (2014) which results in profitability which results in positive disclosure of corporate social responsibility.

Based on the statistical results of this study, with the value of 0.4326 in t test or more than the significance level of 0.05 , this means QR has an insignificant effect. In addition, the result of the coefficient level on QR is - 0.009965 , the value illustrates that QR has a negative effect on the disclosure of corporate social responsibility. Based on that, the liquidity that 
proxied by QR had an insignificant negative effect on the disclosure of corporate social responsibility. is study, compared with research conducted by Mudjiyanti \& Maulani (2017) which produces partial liquidity and produces significant negative. However, this research does not conflict with research conducted by Arif \& Wawo (2016) which produces positive and significant liquidity on disclosure of corporate social responsibility.

Based on the results of this study, the firm size that proxied by total assets has a negative effect that is not significant on the disclosure of corporate social responsibility, this can be proven by the t test results with the value of 0.3312 . The value of 0.3312 is higher than the significance level of 0.05 , this means that ROA has no significant effect. In addition, the result of the coefficient level on ROA is -0.027218 , the value illustrates that the size of the firm has a negative effect on the disclosure of corporate social responsibility. Based on that, it can be concluded that firm size had an insignificant negative effect on the disclosure of corporate social responsibility. This study, is in line with research conducted by Pradnyani \& Sisdyani (2015) which results that company size does not affect disclosure of corporate social responsibility. However, this research is not in line with research conducted by Dermawan \& Deitiana (2014) which results in a positive company size on the disclosure of corporate social responsibility.

Based on the results of this study, with the value of 0.3841 in t test or more than the significance level of 0.05 , this means media exposure has an insignificant effect. In addition, the result of the coefficient level on $Q R$ is -0.057840 , the value illustrates that media exposure has a negative effect on the disclosure of corporate social responsibility. Based on that, the media exposure had an insignificant negative effect on the disclosure of corporate social responsibility.

\section{CONCLUSION}

This study used panel data regression analysis, where panel data is processed using Eviews version 9. The study therefore can be concluded as follows, the Profitability that is proxied by return on assets has an insignificant negative effect on the disclosure of corporate social responsibility on non-banking SOEs listed on the Indonesia Stock Exchange in the period 2013-2017. The Liquidity that is proxied by quick ratio has an insignificant negative effect also on the disclosure of corporate social responsibility. In addition, the size of the firm that proxied by total assets has an insignificant negative effect on the disclosure of corporate social responsibility on non-banking SOEs listed on the Indonesia Stock Exchange in the period 2013-2017. Media exposure has an insignificant negative effect on the disclosure of corporate social responsibility on non-banking SOEs listed on the Indonesia Stock Exchange in the period 2013-2017. This research therefore confirms that all variables above do not have significant effect on CSR disclosure.

\section{REFERENCES}

1. Arif, F., \& Wawo, A. (2016). The Effects of Company Size, Leverage and Liquidity Towards CSR Disclosure. ASSETS, Vol. 6, No. 2.

2. Prilly, A, et al. "Analysis of the Implementation of Corporate Social Responsibility Against Profitability at PT. Bank Tabungan Negara (Persero) TBK ", EMBA Journal, Vol. 4, 2016, pp. 1184.

3. Solihin I., "Corporate Social Responsibility", 2009, pp. 4.

4. Radyati M., Sustainable Business and Corporate Social Responsibility (CSR), Jakarta: Center for Entrepreneurship, 2014.

5. Gitman L. and C. Zutter, "Principles of Managerial Finance", Edinburg, England: Pearson Education Limited, Vol. 14, 2015.

6. Morissan, Public Relations Management: Strategies to Become Human Professionals, Jakarta: Prenada Media Group, 2008.

7. Sugiyono, Quantitative Research Methods, Qualifications and R\&D, Bandung: Alfabeta, 2017. 
8. Cahyono DD, R. Andini, and K. Raharjo, "The Effect of the Audit Committee, Institutional Ownership, Board of Commissioners, Size, Leverage (DER), and Profitability (ROA) on Tax Avoidance Acts (Tax Avoidance) For Companies that Register IDX for the Period of 2011-2013", Journal of Accounting, Vol. 2, No. 2, 2016.

9. Kieso D., J. Weygandt, and T. Warfield, Intermediate Accounting Second Edition IFRS Edition, United States: Wiley, 2014.

10. Anggraeni N. P. and I. N. Budiasih, "The Role of Media Exposure for the Indonesian Capital Market", Journal of the Bulletin of Economic Studies, Vol. 21, No. 1, 2016.

11. Gujarati D., Basic Econometrics, Boston, MA: Mcgraw-Hill, 2003.

12. Pradnyani, I. A., \& Sisdyani, E. A. (2015). Effect of Company Size, Profitability, Leverage, and Board of Commissioners Size of the Udayana Accounting Journal.

13. Generous, D., \& Deitiana, T. (2014, December). Factors That Influence Corporate Social Responsibility Disclosure. Journal of Business and Accounting, Vol. 16, No. 2. 